\title{
Mycoplasma hominis meningitis in an extremely preterm newborn: a case report
}

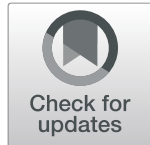

Najmus Sehr Ansari, Elizabeth Asztalos and Asaph Rolnitsky

\begin{abstract}
Background: Mycoplasma Hominis is a micro-organism which is a part of the human genitourinary tract flora. Neonates are susceptible to acquire this pathogen either in utero or through vertical transmission. In rare cases, it may cause central nervous system infections with severe morbidity and mortality in preterm and term neonates.

Case presentation: We present a case of Mycoplasma Hominis meningitis in an extremely preterm neonate who presented with lethargy, tachycardia and seizures on day 7 of life. There was no history of maternal systemic or genitourinary infection during pregnancy and th the time of delivery. Empirical antibiotic therapy for neonatal meningitis was commenced after sending blood and cerebrospinal fluid cultures. Cerebrospinal fluid analysis showed pleocytosis with neutrophilic predominance, but no bacteria was identified on gram staining. Blood culture yielded no growth of any bacterial pathogen. However, growth of Mycoplasma Hominis was suspected in cerebrospinal fluid culture which was confirmed by $16 \mathrm{~S}$ ribosomal ribonucleic acid (RNA) polymerase chain reaction analysis. Subsequently, antibiotics were changed to Moxifloxacin and Doxycycline which were given for a total duration of 6 weeks. Multiple cerebrospinal fluid cultures were performed during this treatment. No growth of any pathogen was identified on any of these cerebrospinal fluid cultures.

Conclusions: We report a rare case of Mycoplasma Hominis meningitis in an extremely preterm neonate which was successfully treated with a combination therapy of Moxifloxacin and Doxycycline.

It is important to consider the possibility of Mycoplasma Hominis meningitis in neonates who present with clinical signs and pleocytosis in cerebrospinal fluid but negative gram staining and no growth on conventional culture media.
\end{abstract}

Keywords: Preterm neonate, Meningitis, Mycoplasma Hominis, Case report

\section{Background}

Mycoplasma Hominis is a frequent habitant of the human genital tract [1]. Neonates are susceptible to acquire this microbe either in utero or through the colonized birth canal during the process of parturition [2]. However, invasive infections with this organism in preterm and term infants are noted to be rare $[1,3]$. We describe an unusual case of neonatal meningitis due to Mycoplasma Hominis, confirmed in bacterial cultures and 16s

* Correspondence: sehransari@hotmail.com

Department of Neonatology Sunnybrook Health Sciences Centre, University of Toronto, 2075 Bayview Avenue, M Wing, M4N 3M5 Toronto, Ontario, Canada

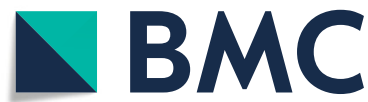

ribosomal RNA Polymerase chain reaction (PCR) analysis. This case report demonstrates the importance of suspecting Mycoplasma Hominis as a cause of central nervous system (CNS) infection in neonates who present with clinical signs but no growth on conventional bacterial cultures and no improvement on empirical antibiotic treatment.

\section{Case presentation}

A male neonate was born at $25+6$ weeks of gestation to 35 years old gravida 2, parity1 (G2P1) mother with antiphospholipid antibody syndrome. This was an in vitro fertilization (IVF) pregnancy. She was Rubella immune

(c) The Author(s). 2021 Open Access This article is licensed under a Creative Commons Attribution 4.0 International License, which permits use, sharing, adaptation, distribution and reproduction in any medium or format, as long as you give appropriate credit to the original author(s) and the source, provide a link to the Creative Commons licence, and indicate if changes were made. The images or other third party material in this article are included in the article's Creative Commons licence, unless indicated otherwise in a credit line to the material. If material is not included in the article's Creative Commons licence and your intended use is not permitted by statutory regulation or exceeds the permitted use, you will need to obtain permission directly from the copyright holder. To view a copy of this licence, visit http://creativecommons.org/licenses/by/4.0/. The Creative Commons Public Domain Dedication waiver (http://creativecommons.org/publicdomain/zero/1.0/) applies to the data made available in this article, unless otherwise stated in a credit line to the data. 
and negative for Hepatitis B surface antigen, Venereal disease research laboratory test (VDRL), Human immunodeficiency virus, Gonococci and Chlamydia. Her urine culture and vaginal swab for Group B Streptococci was also negative. Her anatomy scan at 18 weeks of gestation showed normal fetal anatomy and a short cervix for which she underwent cervical cerclage placement at $20+5$ weeks gestation. There was no history of chorioamnionitis or prolonged rupture of membranes. She presented at $25+5$ weeks with preterm labor and had a spontaneous vaginal delivery the next day. She had received two doses of Betamethasone and Magnesium sulphate prior to delivery. He initially required positive pressure ventilation followed by intubation and surfactant administration with an acceptable response. Umbilical arterial and venous catheters were placed and the neonate was transferred to neonatal intensive care unit (NICU) in a stable condition.

A blood culture was drawn at birth and empiric treatment with Ampicillin and Gentamicin was intiated. The antibiotics were discontinued after 36 hours as the blood culture showed no growth and he remained clinically stable. In addition, as per unit protocol, an endotracheal aspirate was sent for a Ureaplasma culture on admission. This grew a Mycoplasma species for which 3 days of intravenous Azithromycin was given.

A head ultrasound on day 4 of life showed bilateral intraventricular hemorrhage (grade 3) with mild ventriculomegaly and a hemorrhagic venous infarct in the right frontoparietal region. Umbilical arterial catheter was removed on day 4 of life whereas umbilical venous catheter was removed on day 6 of life. He remained stable till day 7 of life when he presented with an acute clinical deterioration presenting as lethargy and tachycardia; a septic work up including blood and cerebrospinal fluid (CSF) cultures was completed and Vancomycin and Cefotaxime were started as empiric antibiotics. His CSF analysis showed red blood cells (RBC) count of $4887 \times$ 10E6/l, pleocytosis of white blood cells (WBC) $9620 \times$ 10E6/l with neutrophilic predominance, hyperproteorachia - protein $8300 \mathrm{mg} / \mathrm{l}$ and hypoglycorachia - glucose $0.1 \mathrm{mmoles} / \mathrm{liter}$. Gram staining in CSF was negative. Within hours he developed generalized clinical seizures which was treated with Lorazepam and Phenobarbital followed by a Levetiracetam load and maintenance dose. $\mathrm{He}$ had further episodes of clinical and subclinical seizures which resolved after further adjustment of levetiracetam doses.

His first CSF culture was suspected to grow Mycoplasma Hominis and was sent to the regional national diagnostic laboratory for confirmation. The CSF culture was repeated along with a sample for 16s ribosomal RNA PCR analyses. The 16s ribosomal RNA PCR analysis confirmed Mycoplasma hominis in both CSF samples. Antibiotics were then changed to Moxifloxacin and Doxycycline. The repeat CSF culture after 48 hours of Moxifloxacin and Doxycycline showed no growth. CSF analysis done seven days after starting this treatment showed RBC $5650 \times 10 \mathrm{E} 6 / \mathrm{l}$, WBC $449 \times 10 \mathrm{E} 6 / \mathrm{l}$, protein $3763 \mathrm{mg} / \mathrm{l}$ and glucose $0.2 \mathrm{mmoles} / \mathrm{liter}$. Subsequent CSF findings repeated after another three days showed further improvement, RBC $7187 \times 10 \mathrm{E} 6 / \mathrm{l}$, WBC $93 \times 10 \mathrm{E} 6 / \mathrm{l}$, protein $3691 \mathrm{mg} / \mathrm{l}$ and glucose $0.5 \mathrm{mmoles} /$ liter. No growth was seen on any of these CSF cultures. Serial head ultrasound scans were done which showed progressive ventriculomegaly, post hemorrhagic ventricular dilatation and cystic evolution of hemorrhagic/ venous infarct in the right frontoparietal region. Although these findings could be attributed to extreme prematurity; there is a likelihood that infection with Mycoplasma Hominis may have played a role in its progression. There have been documented cases of Mycoplasma Hominis meningitis resulting in CNS complications including intraventricular and periventricular hemorrhage, hydrocephalus, and infarction [3]. Lumbar taps were repeated as therapeutic measure to reduce ventriculomegaly, but optimal volumes of CSF were not obtained. Because of the ventriculomegaly, he was evaluated for a possible shunt on day 31 ; this was deferred because of the stable ventriculomegaly.

Antibiotics were given for a total duration of six weeks after which he was discharged home with a normal neurological examination. He was referred to Neurodevelopmental clinic for follow-up.

\section{Discussion and conclusion}

Neonatal CNS infections with Mycoplasma Hominis, although rare, can cause severe morbidity and mortality in neonates [1]. In a case series of 29 neonates with Mycoplasma Hominis infection (age of presentation day1-32 of life), Hata and colleagues reported complications such as brain abscess, hydrocephalus, infarction, cerebritis and periventricular/intraventricular hemorrhage in $34 \%$ cases, death in $28 \%$ and sequelae mostly hemiparesis in another $28 \%$ cases [3]. This may be attributed to a delay in diagnosis, ineffective antibiotic treatment, or suboptimal treatment regimens for neonatal CNS disease $[3,4]$. Therefore, prompt diagnosis, early initiation and optimal duration of appropriate antibiotic therapy is necessary for a favorable prognosis.

The clinical presentation may include apnea, temperature instability, lethargy, vomiting, irritability poor tone, twitching or seizures [7]. Detection of Mycoplasma Hominis can be challenging since they lack peptidoglycan cell wall which renders them unidentifiable by gram staining [5]. In addition to this, they grow very slowly on routine culture media and require a specific blood agar medium for their detection $[1,6]$. Due to this, 
Table 1 Characteristics of neonates treated with combination therapy (Moxifloxacin and another antibiotic) for Mycoplasma Hominis CNS infection

\begin{tabular}{|c|c|c|c|c|c|c|c|}
\hline & $\begin{array}{l}\text { Gestational } \\
\text { Age }\end{array}$ & $\begin{array}{l}\text { Age at } \\
\text { presentation }\end{array}$ & $\begin{array}{l}\text { Clinical } \\
\text { presentation }\end{array}$ & $\begin{array}{l}\text { Confirmation } \\
\text { of diagnosis }\end{array}$ & $\begin{array}{l}\text { Empirical antibiotic } \\
\text { therapy and duration }\end{array}$ & $\begin{array}{l}\text { Antibiotics for } \\
\text { Mycoplasma } \\
\text { Hominis }\end{array}$ & Outcome \\
\hline $\begin{array}{l}\text { Hata and } \\
\text { colleagues }^{3}\end{array}$ & 38 weeks & 25 days & $\begin{array}{l}\text { Fever, } \\
\text { vomiting, } \\
\text { focal seizures }\end{array}$ & $16 S$ RNA PCR & $\begin{array}{l}\text { Ampicillin \& Cefotaxime } \\
\text { (day 1-2) Ciprofloxacin (day } \\
6-17 \text { ) Acyclovir (day 6-8) } \\
\text { Chloramphenicol (day 8- } \\
\text { 17) }\end{array}$ & $\begin{array}{l}\text { Minocycline for } \\
28 \text { days (day } 6- \\
34 \text { ) } \\
\text { Moxifloxacin } \\
\text { for } 17 \text { days } \\
\text { (day } 17-34 \text { ) }\end{array}$ & $\begin{array}{l}\text { Recovery with left } \\
\text { hemiplegia }\end{array}$ \\
\hline $\begin{array}{l}\text { Watt and } \\
\text { colleagues }^{5}\end{array}$ & 26 weeks & 7 days & $\begin{array}{l}\text { Apnea, } \\
\text { hypotonia, } \\
\text { generalized } \\
\text { seizures }\end{array}$ & $16 S$ RNA PCR & $\begin{array}{l}\text { Ampicillin and Gentamycin } \\
\text { (day1-8) Ceftazidime (day } \\
1-5 \text { ) Vancomycin (day 8- } \\
19 \text { ) Acyclovir (day 8-19) } \\
\text { Meropenem (day 12-19) }\end{array}$ & $\begin{array}{l}\text { Doxycycline for } \\
6 \text { weeks (day } \\
\text { 19-60) } \\
\text { Moxifloxacin } \\
\text { for } 6 \text { weeks } \\
\text { (day 19-60) }\end{array}$ & $\begin{array}{l}\text { Recovery, neurological } \\
\text { outcomes not reported }\end{array}$ \\
\hline Our case & $25+6$ weeks & 7 days & $\begin{array}{l}\text { Lethargy, } \\
\text { tachycardia, } \\
\text { generalized } \\
\text { seizures }\end{array}$ & $16 S$ RNA PCR & $\begin{array}{l}\text { Ampicillin and Gentamycin } \\
\text { (day 1-2) Azithromycin } \\
\text { (day 3-6) Vancomycin and } \\
\text { cefotaxime (day 7-10) }\end{array}$ & $\begin{array}{l}\text { Doxycycline for } \\
6 \text { weeks (day } \\
10-52 \text { ) } \\
\text { Moxifloxacin } \\
\text { for } 6 \text { weeks } \\
\text { (day 10-52) }\end{array}$ & $\begin{array}{l}\text { Recovery with normal } \\
\text { neurological examination } \\
\text { at discharge, follow up at } \\
6 \text { months showed normal } \\
\text { neurological examination }\end{array}$ \\
\hline
\end{tabular}

there is a likelihood that Mycoplasma Hominis infections may remain undiagnosed or diagnosed late in infants presenting with clinical signs and symptoms [2]. Hence, it is important to consider the possibility of Mycoplasma Hominis infection in cases where the CSF shows pleocytosis and no growth of organism on routine culture media. A 16S ribosomal RNA PCR analysis has proven useful for detection of Mycoplasma Hominis in blood and CSF which are difficult to grow on standard culture media $[7,8]$. The microbe is identified by direct sequencing analysis after amplification by PCR. Use of pathogen-specific primers in 16S RNA analysis results in rapid detection of the specific organism [4]. Prematurity, low birth weight, and neural tube defects are recognized to be the most common risk factors for neonatal meningitis with Mycoplasma Hominis [6]. However, it has also been seen in term neonates with no neurological birth malformations [1, 3].

The treatment options for Mycoplasma Hominis meningitis and its duration remains unclear [1,9]. Due to the rarity of this infection in neonates, the current recommendations are based on clinical experiences and invitro susceptibility test results $[9,10]$.

Mycoplasma Hominis has shown susceptibility to Chloramphenicol, Tetracyclines, Lincosamide and Fluoroquinolones in in-vitro testing [11]. Fluoroquinolones have been used in past to treat neonatal mycoplasma hominins meningitis successfully $[1,3,5]$. Moxifloxacin, a fourth-generation fluoroquinolone is preferred because of its ability to concentrate in CSF and its bactericidal effects in CNS infections $[1,12,13]$. Although there are cases which were successfully treated with Moxifloxacin monotherapy $[1,6]$, there is a risk of development of resistance with fluoroquinolones during treatment [9, $14,15]$. Our literature search revealed only two reported cases of neonates who were given Moxifloxacin in combination with another antibiotic for Mycoplasma Hominis meningitis $[3,5]$ (Table 1$)$.

Evidence from previously published cases show that 28 \% neonates with Mycoplasma Hominis CNS infection died whereas $34 \%$ had some CNS complications and $28 \%$ cases developed some neurological sequelae mostly hemiparesis [3]. In our case, treatment with a combination therapy of Moxifloxacin and Doxycycline resulted in significant clinical and laboratory improvement in terms of negative CSF culture after 48 hours of initiating this regimen and decreased WBC count and protein in subsequent CSF analysis. Our patient was discharged home with a normal neurological examination and stable ventriculomegaly. His neurodevelopmental follow up at six months of age showed normal neurological findings.

It is important to consider Mycoplasma Hominis as a potential cause for neonatal meningitis in infants particularly those with previous colonization with this rare but devastating species. Our case demonstrates effective eradication of Mycoplasma Hominis with a combination therapy of Moxifloxacin and Doxycycline. However, further research is required to understand the pharmacokinetics of these antibiotics to establish optimal dosing and duration for effective treatment of CNS infections with Mycoplasma Hominis.

\section{Abbreviations}

G2P1: Gravida2, Parity1; PCR: Polymerase chain reaction;

RNA: Ribonucleic acid; IVF: In vitro fertilization; CSF: Cerebrospinal fluid; 
RBC: Red blood cells; WBC: White blood cells; CNS: Central nervous system; VDRL: Venereal disease research laboratory test; NICU: Neonatal intensive care unit

\section{Acknowledgements}

Not applicable.

\section{Authors' contributions}

NSA, EA, and AR conceptualized the idea of writing this case report. NSA drafted the initial manuscript which was revised by AR and EA. AR and EA supervised the literature review for this case study, critically reviewed the manuscript, and approved the final version.

\section{Funding}

No funding received from any public, commercial or non-profit organization.

\section{Availability of data and materials}

Not applicable.

\section{Ethics approval and consent to participate}

None.

\section{Consent for publication}

Written informed consent was obtained from patient's parents for publication of this case report.

\section{Competing interests}

The authors declare that they have no competing interests.

Received: 30 September 2020 Accepted: 2 February 2021

Published online: 08 February 2021

\section{References}

1. Wildenbeest JG, Said I, Jaeger B, van Hest RM, van de Beek D, Pajkrt D. Neonate with Mycoplasma hominis meningoencephalitis given moxifloxacin. Lancet Infect Dis. 2016;16(11):e261-6. https://doi.org/10.1016/ S1473-3099(16)30162-1.

2. Knausz M, Niederland T, Dósa E, Rozgonyi F. Meningo-encephalitis in a neonate caused by maternal Mycoplasma hominis treated successfully with chloramphenicol. J Med Microbiol. 2002;51(2):187-8. https://doi.org/10.1099/ 0022-1317-51-2-187.

3. Hata A, Honda Y, Asada K, Sasaki Y, Kenri T, Hata D. Mycoplasma hominis meningitis in a neonate: case report and review. J Infect. 2008;57(4):338-43. https://doi.org/10.1016/j.jinf.2008.08.002.

4. Taku K, Hoshina T, Haro K, et al. An infant case with hydrocephalus as the initial manifestation of Mycoplasma hominis-associated meningitis. J Infect Chemother. 2017:23(10):713-16. https://doi.org/10.1016/j.jiac.2017.03.012.

5. Watt KM, Massaro MM, Smith B, Cohen-Wolkowiez M, Benjamin DK Jr, Laughon MM. Pharmacokinetics of moxifloxacin in an infant with Mycoplasma hominis meningitis. Pediatr Infect Dis J. 2012;31(2):197-99. https://doi.org/10.1097/INF.0b013e31823980c3.

6. Nohren J, Namtu K, Peloquin C, Messina A, Tuite G, Berman DM. The pharmacokinetics of moxifloxacin in cerebrospinal fluid following intravenous administration: a report of successfully treated infant with mycoplasma hominis meningitis. Pediatr Infect Dis J. 2020;39(8):e183-4. https://doi.org/10.1097/INF.0000000000002655

7. Woo PC, Lau SK, Teng JL, Tse H, Yuen KY. Then and now: use of $16 \mathrm{~S}$ rDNA gene sequencing for bacterial identification and discovery of novel bacteria in clinical microbiology laboratories. Clin Microbiol Infect. 2008;14(10):90834. https://doi.org/10.1111/j.1469-0691.2008.02070.x.

8. Mignard S, Flandrois JP. $16 \mathrm{~S}$ rRNA sequencing in routine bacterial identification: a 30-month experiment. J Microbiol Methods. 2006;67(3):57481. https://doi.org/10.1016/j.mimet.2006.05.009.

9. Krausse R, Schubert S. In-vitro activities of tetracyclines, macrolides, fluoroquinolones and clindamycin against Mycoplasma hominis and Ureaplasma ssp. isolated in Germany over 20 years. Clin Microbiol Infect. 2010;16(11):1649-55. https://doi.org/10.1111/j.1469-0691.2009.03155.x.

10. Waites KB, Katz B, Schelonka RL. Mycoplasmas and ureaplasmas as neonatal pathogens. Clin Microbiol Rev. 2005;18(4):757-89. https://doi.org/10.1128/ CMR.18.4.757-789.2005
11. Watson L, Pang YM, Mitchell S, Dodgson A. Mycoplasma hominis meningitis in a 24 week premature neonate: case report and short literature review. J Pediatr Pharmacol Ther. 2008;13(4):251-54. https://doi.org/10.5863/15516776-13.4.251.

12. Alffenaar JW, van Altena R, Bökkerink HJ, et al. Pharmacokinetics of moxifloxacin in cerebrospinal fluid and plasma in patients with tuberculous meningitis. Clin Infect Dis. 2009;49(7):1080-82. https://doi.org/10.1086/ 605576.

13. Di Paolo A, Gori G, Tascini C, Danesi R, Del Tacca M. Clinical pharmacokinetics of antibacterials in cerebrospinal fluid. Clin Pharmacokinet. 2013:52(7):511-42. https://doi.org/10.1007/s40262-013-0062-9.

14. Bebear CM, Bové JM, Bebear C, Renaudin J. Characterization of Mycoplasma hominis mutations involved in resistance to fluoroquinolones. Antimicrob Agents Chemother. 1997;41(2):269-73. https://doi.org/10.1128/AAC.41.2.269.

15. Meng DY, Sun CJ, Yu JB, Ma J, Xue WC. Molecular mechanism of fluoroquinolones resistance in Mycoplasma hominis clinical isolates. Braz J Microbiol. 2014:45(1):239-42.

\section{Publisher's Note}

Springer Nature remains neutral with regard to jurisdictional claims in published maps and institutional affiliations.

\section{Ready to submit your research? Choose BMC and benefit from:}

- fast, convenient online submission

- thorough peer review by experienced researchers in your field

- rapid publication on acceptance

- support for research data, including large and complex data types

- gold Open Access which fosters wider collaboration and increased citations

- maximum visibility for your research: over $100 \mathrm{M}$ website views per year

At BMC, research is always in progress.

Learn more biomedcentral.com/submissions 